Article

\title{
Points of Consideration on Climate Adaptation of Solar Power Plants in Thailand: How Climate Change Affects Site Selection, Construction and Operation
}

\author{
Kampanart Silva *, Pidpong Janta and Nuwong Chollacoop
}

Citation: Silva, K.; Janta, P.; Chollacoop, N. Points of Consideration on Climate Adaptation of Solar Power Plants in Thailand: How Climate Change Affects Site Selection, Construction and Operation. Energies 2022, 15, 171 https://doi.org/10.3390/en15010171

Academic Editor: Dolf Gielen

Received: 15 November 2021

Accepted: 20 December 2021

Published: 28 December 2021

Publisher's Note: MDPI stays neutral with regard to jurisdictional claims in published maps and institutional affiliations.

Copyright: (C) 2021 by the authors. Licensee MDPI, Basel, Switzerland. This article is an open access article distributed under the terms and conditions of the Creative Commons Attribution (CC BY) license (https:// creativecommons.org/licenses/by/ $4.0 /$ )
Renewable Energy and Energy Efficiency Research Team, National Energy Technology Center, National Science and Technology Development Agency, Pathum Thani 12120, Thailand; pidpong.jan@entec.or.th (P.J.); nuwong.cho@entec.or.th (N.C.)

* Correspondence: kampanart.sil@entec.or.th; Tel.: +66-87-812-0502

\begin{abstract}
Solar energy is planned to undergo large-scale deployment along with Thailand's transformation to a carbon neutral society in 2050. In the course of energy transformation planning, the issue of energy infrastructure adaptation to climate change has often been left out. This study aims to identify climate-related risks and countermeasures taken in solar power plants in Thailand using thematic analysis with self-administered observations and structured interviews in order to propose points of consideration during long-term energy planning to ensure climate adaptation capacity. The analysis pointed out that floods and storms were perceived as major climate events affecting solar power plants in Thailand, followed by lightning and fires. Several countermeasures were taken, including hard countermeasures that require extensive investment. Following policy recommendations were derived from the climate-proofing investment scenario study. Policy support in terms of enabling regulations or financial incentives is needed for implementation of climate-proofing countermeasures. Public and private sectors need to secure sufficient budget for fast recovery after severe climate incidents. Measures must be taken to facilitate selection of climate-resilient sites by improving conditions of power purchase agreement or assisting winning bidders in enhancing climate adaptability of their sites. These issues should be considered during Thailand's long-term energy planning.
\end{abstract}

Keywords: climate adaptation; adaptive capacity; solar power plants; thematic analysis; long-term energy scenarios (LTES); site selection; power purchase agreement

\section{Introduction}

The 26th UN Climate Change Conference of the Parties (COP26) [1] drew the world a bit closer to net zero greenhouse gas (GHG) emission, or so-called climate neutrality [2]. From the Kyoto Protocol [3] in 1998 to the Paris Agreement [4] in 2015, voluntary emission reduction targets changed to Nationally Determined Contributions (NDCs) that should be updated every five years. COP26 was the first opportunity for countries to update their NDC, where top runners came up with ambitious emission reduction target in 2030 in order to achieve net zero emission by or before $2050[5,6]$, and consequently maintain the global warming to $1.5^{\circ} \mathrm{C}$ [7]. With a new financial support scheme to facilitate more proactive emission reduction in developing countries [8], a number of developing countries decided to declare a more stringent target than the NDC updated in 2020 in COP26. There was no exception for Thailand. Thailand stated in the updated NDC that it will reduce the GHG emission by $25 \%$ by 2030 with adequate access to technological, financial, and capacity building support [9]. In COP 26, apart from updating to the more ambitious emission reduction target of $40 \%$ by 2030 , Thailand revealed its plan to achieve carbon neutrality by 2050 and consequently net zero emission by or before 2065 [10]. These updated national targets reflect the achievement of an important milestone of the global roadmap toward 
climate neutrality. At the same time, they oblige all countries to put forward enabling policies that can support GHG emission reduction. The energy sector is the sector that most countries set a strict emission reduction target on since it accounts for one-fourth of the total global emissions [11]. International and regional entities, e.g., International Renewable Energy Agency (IRENA) [12], Asia-Pacific Economic Cooperation (APEC) [13], Association of Southeast Asian Nations (ASEAN) [14], have been promoting increase in share of renewable energy in electricity and heat production portfolio of each country to replace carbon-intensive energy sources. In order to get in line with this trend, the new National Energy Plan of Thailand to be launched in 2022 includes an ambitious goal to increase the share of renewable energy in electricity and heat production to at least $50 \%$ by $2050[15,16]$. The share of renewable energy can be even higher to accommodate the updated targets in COP26.

Long-term energy scenarios (LTES) is an important tool to facilitate the achievement of the aforementioned renewable energy goals. It enables usage of scenario planning for strategic decision-making and helps account for potential transformational changes in energy sector [17]. Thanks to the updated NDCs mentioned above, renewable energy will play the most significant role ever in global energy transformation [18]. This leads to several additional considerations during the long-term energy planning. On the downside, intermittent nature of some renewable energy sources introduces a new challenge in ensuring operational flexibility in the planning of energy transition [19]. Energy storage can be one of the solutions to it, though balance between cost and flexibility should be carefully considered [20]. On the other hand, apart from mitigating the climate change impact, transition from non-renewable energy to renewable energy can contribute to energy security and job creation [21]. Particularly in developing countries, it can also accelerate energy access [22] and contribute to economic growth [23]. All these aspects have to be appropriately taken into account during long-term energy planning, and they have been done so in many economies, including Thailand [24].

One of the issues that have often been left out during energy transformation planning is the adaptation of energy infrastructure to climate change. Goal 13: Climate Actions of the UN SDGs requires the nations to strengthen resilience and adaptive capacity of critical infrastructure, including energy infrastructure, to climate-related hazards and natural disasters [25]. To date, 125 out of 154 developing countries are formulating and implementing national climate adaptation plans in which key economic sectors and services, including electricity generation, is incorporated in the highest priority areas of the plans [26]. This is because increasing intensity and frequency of climate hazards due to climate change can significantly affect the ability of the energy system to meet the electricity demand [27]. This results in additional investment not only to ensure the fulfillment of electricity demand, but also to enhance the energy infrastructure resilience [28]. Efforts have also been made to capture and monitor resilience of the energy infrastructure and its surroundings toward climate hazards during the transition toward renewable energy-intensive system [29] to ensure a smooth transformation. Therefore, a clear picture of effects from climatic events on energy infrastructure and the ways that the system can adapt to this change to make itself more resilient should be correctly illustrated in order to incorporate climate adaptation strategy into energy transformation planning.

Climate adaption has rarely been discussed under the framework of energy planning in Thailand. The latest Power Development Plan revised in late 2020 focuses on designing energy portfolio in order to ensure energy security, maintain appropriate power generation cost, and limit carbon dioxide emission [30]. On the other hand, energy infrastructure is only included as a part of the human settlements and security sector in Thailand's National Adaptation Plan (NAP). The plan promotes adoption of adaptive design in energy facilities to become climate resilient architecture, and development of emergency power production systems to ensure quality living during natural disasters [31]. However, this has not yet been adequately considered in national energy policymaking. Therefore, this study aims to trigger a dialogue between energy and climate policymakers on climate 
adaptation of energy infrastructure during the transition to a renewable energy-based society. The discussion on the ways to equip climate adaptive capacity to the renewable energy infrastructure to serve the ambitious GHG emission reduction target announced at COP26 could serve as a good starting point.

In a preparatory meeting for COP26 [32], several scenarios were proposed for energy sector in order to meet the target, including:

1. $50 \%$ renewable energy by 2050 and $69 \%$ electric vehicles by 2035 ;

2. $50 \%$ renewable energy by 2050 and $100 \%$ electric vehicles by 2035 , and;

3. $75 \%$ renewable energy by 2050 and $69 \%$ electric vehicles by 2035 .

All scenarios largely rely on solar energy, making its share as large as $37-56 \%$ of the total electricity and heat generation in 2050. This is due to the fact that Thailand, which is located in tropical climate zone, has higher solar radiation intensity than countries in temperate or dry climate zones [33]. In addition, the average wind speed in Thailand is relatively low which limits the suitable area for wind power plants [34], even though the global average levelized cost of electricity production by wind is equally low as solar photovoltaic [12,35]. The costs of bioenergy and waste-to-energy power plants are also too high to encourage a large-scale country-wide penetration. Hence, it seems reasonable to start the dialogue with the discussion on climate adaptation capacity of solar photovoltaic systems.

Scholars and practitioners have been using quantitative risk assessments as the basis for the consideration of climate adaptability of solar power plants and other energy infrastructures. Projections of precipitation [36-38], natural hazards' returning periods [39,40], resulting economic losses [41,42], are among the quantitative results that have been used to define the risks to solar power plants. Climate adaptation countermeasures have been derived combining these climate risks to the exposures of power plants and the vulnerabilities of those power plants toward climate risks [43-45]. Nevertheless, solar power plants in Thailand still face disruptions from climate-related events, which leads to a problem statement of whether there are other appropriate approaches to capture the climate-related risks of solar power plants in Thailand and design adaptive strategies for them to survive climate change. Since most past studies adopted a quantitative approach, this study will employ a qualitative approach. Therefore, the objective of this study is to use a qualitative approach to capture climate-related risks that are associated to solar power plants in Thailand, particularly solar farms, and the countermeasures that have been taken to adapt to the new climatic normal, in order to propose points of consideration during long-term energy planning to ensure climate adaptation capacity of the systems. The study adopted thematic analysis to identify climate-related risks and possible countermeasures, and uses triangulation of observations, interviews, and literatures to confirm the validity of the results. It then compared scenarios with and without climate-proofing investment in order to derive recommendations on the ways to contemplate climate adaptation of solar power plants during the long-term energy planning.

\section{Methodology}

This study adopted qualitative methods, namely structured in-depth interviews and self-administered observation. While a number of past studies [46-50] applied quantitative methodology, for example, cost-benefit analysis (CBA), to assess economic feasibility, resulting in net present value (NPV), benefit-cost ratio (B/C ratio) or return period, few studies attempted using qualitative methodology to examine perspectives and knowledge grounded in human experiences [51]. This kind of methodology offers a perspective contrary to quantitative methodology to realize insights on why people interact or engage in a particular action [52]. Human insights emerge and can be grasped when qualitative methodology applies, and aspect and engagement experience are derived from targeted persons. Thematic analysis is considered easy to grasp. It highlights key issues, and creates reflective insights from large dataset through flexible, yet well-structured approach with ability to adapt to different studies, proving richness in description [51]. Therefore, thematic analysis can be seen complementing $\mathrm{CBA}$, giving perspectives from primary data gathered 
from person in charge. As two qualitative methods were employed to collect data, it is important to conduct the analysis in rigorous and methodical manners to obtain robust, constructive, and useful findings [53].

\subsection{Data Collection}

To capture climate-related risks and countermeasures, data collection involves two phases as shown in Figure 1. Before proceeding to the first phase, targeted solar power plants for the self-administered observation were selected out of the Thailand's Energy Regulatory Commission (ERC) database which cover 564 solar power plants (as of August 2021). The first phase aimed to gain the bird-eye view of solar power plants' climate adaptive capacity across all four regions in Thailand where 35 sites were selected.

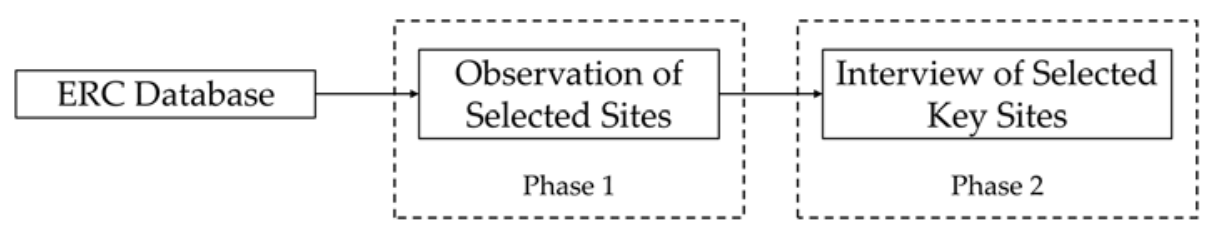

Figure 1. Data collection flow.

The criteria to select solar power plant sites involved verbal or written consent from the enterprise and COVID-19 regulatory approval to enter the site. Summary of the attributes of selected sites are shown in Table 1. This first phase was carried out through free discussion and field observations without interview structure and observation form, but only notes of synopsis of relevant climate issues. Table 2 shows observed items that could influence climate adaptability of the targeted solar power plants which were categorized into power plant-related, climate-related, and others. The notes of each item are used as inputs for the construction of the interview structure in the second phase.

Table 1. Selected solar power plants for self-administered observation.

\begin{tabular}{cccc}
\hline No. & Region & No. of Plant & Range of Contracted Capacity (MW) \\
\hline 1 & Northern & 6 & $0.02-90 \mathrm{MW}$ \\
2 & Northeastern & 13 & $1.02-8 \mathrm{MW}$ \\
3 & Central & 8 & $0.05-2 \mathrm{MW}$ \\
4 & South & 8 & $2-8 \mathrm{MW}$ \\
\hline
\end{tabular}

The findings of free discussion and field observation could vary, ranging from climate issues/risks, vulnerabilities, responses, to future operation plans. The second phase involved structured in-depth interviews and self-administered observation in which the structure referred to the findings from the first phase's synopsis. The structured interviews shown in Table 3 were designed based on not only the synopsis from the first phase but also literatures on climate risks in solar power plants for the second phase. The interviews were planned and aimed only for key sites.

Table 4 illustrates key solar power plant sites and their characteristics. Each key site is established and located in different regions in Thailand with variation in temperature, season, precipitation, climate-related risks, and frequency of climatic events. Climate adaptation countermeasures applied to each key site could be diverse. Essentially, selected commercial sites are taken responsibility by experienced operators who are accountable for several sites under respective enterprises. The results from in-depth interviews are expected to be fruitful and diverse in detail. As a result, key targeted solar power plant sites comprised of a demonstration site (state-owned) in northern region and three commercial sites in northeastern, central, and south regions. 
Table 2. Observed items from solar power plant self-administered observations.

\begin{tabular}{cll}
\hline No. Category & \multicolumn{1}{c}{ Item } \\
\hline & & Monitoring system \\
& Control room \\
& Inverter (brand/capacity) \\
& & Junction box \\
& Photovoltaic panel (brand/capacity) \\
& Damaged or aged component (e.g., PV, mounting \\
& structure) \\
& Grid-connected system \\
& Climate alert/alarm \\
& Consequences of climate events (if any) \\
& Pre-disaster adaptive countermeasure \\
& & Post-disaster adaptive countermeasure \\
& Surroundings (farm/field/accessible road) \\
& Canal (if any) \\
& Water pond (if any) \\
& Lightning conductor (if any) \\
& Area under panel (waterlogged/weeds/dried \\
& soil/cement) \\
& Terrain (slope/flat) \\
\hline
\end{tabular}

Table 3. Areas, sub-areas and supportive references for structured interviews.

\begin{tabular}{|c|c|c|c|c|}
\hline No. & Area & Sub-Area & Item & Reference \\
\hline 1 & $\begin{array}{c}\text { General } \\
\text { information }\end{array}$ & Power plant & $\begin{array}{ll}\text { 1. } & \text { Location } \\
\text { 2. } & \text { Capacity }\end{array}$ & {$[54-57]$} \\
\hline 2 & Establishment & Condition & $\begin{array}{ll}\text { 1. } & \text { Solar radiation } \\
\text { 2. } & \text { Location selection } \\
\text { 3. } & \text { Cost-effectiveness } \\
\text { 4. } & \text { Geographical condition } \\
\text { 5. } & \text { Weather condition }\end{array}$ & [54,56-59] \\
\hline \multirow[t]{2}{*}{3} & \multirow[t]{2}{*}{ Risk } & Natural Risk & $\begin{array}{ll}\text { 1. } & \text { Flood } \\
\text { 2. } & \text { Lightning strike } \\
\text { 3. } & \text { Tropical storm } \\
\text { 4. } & \text { Heavy rainfall } \\
\text { 5. } & \text { Forest fire } \\
\text { 6. } & \text { Extreme heat } \\
\text { 7. } & \text { Cloud cover }\end{array}$ & {$[54,60,61]$} \\
\hline & & Human-made risk & $\begin{array}{ll}\text { 1. } & \text { Chemical use } \\
\text { 2. } & \text { Celebration firework } \\
\text { 3. } & \text { Animal hunt } \\
\text { 4. } & \text { Lawn mowing accidents }\end{array}$ & {$[54,62]$} \\
\hline 4 & Damage & $\begin{array}{c}\text { Natural incident } \\
\text { consequence } \\
\text { Human-made incident } \\
\text { consequence }\end{array}$ & $\begin{array}{ll}\text { 1. } & \text { Property } \\
\text { 2. } & \text { Economic loss } \\
\text { 3. } & \text { Opportunity loss }\end{array}$ & {$[55,56,63]$} \\
\hline 5 & $\begin{array}{l}\text { Strategies } \\
\text { and actions } \\
\text { towards } \\
\text { climate } \\
\text { events }\end{array}$ & $\begin{array}{c}\text { Implemented strategies } \\
\text { and actions } \\
\text { Unimplemented } \\
\text { strategies and actions } \\
\text { Unknown strategies } \\
\text { and actions }\end{array}$ & & {$[61,64,65]$} \\
\hline
\end{tabular}


Table 3. Cont.

\begin{tabular}{ccccc}
\hline No. & Area & Sub-Area & Item & Reference \\
\hline \multirow{2}{*}{$\begin{array}{c}\text { Climate } \\
\text { adaptation } \\
\text { countermea- } \\
\text { sures }\end{array}$} & & & \\
& & & \\
\hline
\end{tabular}

Table 4. Key solar power plants for structured interviews.

\begin{tabular}{cc}
\hline Key Solar Power Plant & Characteristics \\
\hline Key site 1 (KS1) & Demonstration plant (state-owned), northern region \\
Key site 2 (KS2) & Commercial plant, northeast region \\
Key site 3 (KS3) & Commercial plant, central region \\
Key site 4 (KS4) & Commercial plant, south region \\
\hline
\end{tabular}

\subsection{Data Analysis}

As stated above, this study employed thematic analysis [76] to analyze and convert raw data into useful and applicable results. Thematic analysis is beyond simply summarizing obtained data, but interprets into decent themes [77]. This study adopted the thematic analysis proposed by Braun and Clarke [76] comprises of six procedures: reviewing raw data, creating initial codes, categorizing codes into themes, polishing theme, defining themes, and reporting results. To conduct such analysis, consistency of procedures should be systematically fostered from phase to phase [78]. To ensure reliability of data obtained from interviews and observation, trustworthiness criteria created by Lincoln and Guba [79] involving creditability, transferability, dependability, confirmability, and audit trails, was adopted and applied to each phase of the analysis. The criteria are known as essential qualitative instruments to enhance the worthy of research finding, being able to grab researchers and readers attention [80].

\subsection{Confirming Validity of Study}

By nature, validity in analysis process and findings of a qualitative study is always questioned. Data triangulation was employed ensure data accuracy, reflecting actual context with adequate creditability [81]. The method is generally used to help qualitative researchers establish validity. The method involves integrating sources of data/information to create strong foundation. In this study, structured interview form was designed based on the synopsis of climate-related issues from previous free discussion and with support of literature studies in order to ensure that in-depth interviews are conducted meticulously and cover essential points of discussion. As can be seen in Table 3, each interview item derived from the first phase and firmly supported by literature. They were categorized into five areas and nine sub-areas. Additionally, climate adaption countermeasures were included to actively interact with interviewees and efficiently carry out the interviews. Data triangulation in Figure 2 demonstrates a mixture of self-administered observation, thematic analysis-derived insights of in-depth interviews, and literature, that was used to produce research findings in this study.

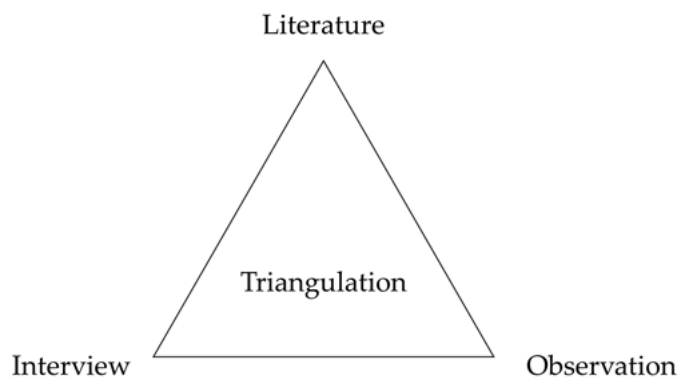

Figure 2. Data triangulation employed in the study. 


\section{Results}

To realize climate-related risks in solar power plants and how the risks are managed, self-administered observation on 35 solar power plants were carried out which aimed to investigate operation strategies on climate-related risks. The 35 solar power plants belong to seven well-known solar power enterprises that make up the majority of solar power capacity in Thailand, as well as three small enterprises and one university-owned power plant. Synopsis of the discussion revealed that site selection is an important issue in solar power plant investment. Plant operators indicated that there had been several essential factors to determine site locations, for example, solar radiation, weather and geographical conditions, vulnerabilities to natural climate events, and availability of power distribution grid. Among the factors, solar radiation is the most important criterion to be taken into account [82]. Amount of solar energy should meet minimum standard [83]. In terms of economic aspect, solar power plants are encouraged to be located near power grid and substations to minimize investment cost [49], and to make it convenient for maintenance [84]. On the other hand, plant operators claimed that environmental factors such as weather and geographical conditions, and vulnerabilities of natural climate events are among critical factors which aligned well with literature [34,35,46,82,83]. Additionally, studies indicated that solar power plants should not be located in forest, agricultural area, water pathways, dams, and flood areas [54,85]. This is not only to minimize of environmental impact, but also to avoid natural climate events [86], especially flood and storm which are the major climate events in Thailand [87].

The self-administered observation and open informal conversation in the first phase were insufficient to reveal the true rationale of climate adaptability of solar power plants. The study was furthered to examine site selection criteria that contribute to prevention and mitigation of climate events. In-depth interviews with four key sites and further field observations were conducted, and thematic analysis were employed and systematically applied to all transcribed data obtained from the interviews and observations. Data consisted of a 93-page-transcript from 3-h and 12-min-long interviews. The results from thematic analysis are presented in Table 5. Two key theme clusters: Climate-related risks and Location selection were derived from the process.

\subsection{Climate-Related Risks}

As shown in Table 6, flood and storm, forest fire, and lightning were climate-related risks indicated from four key solar power plant sites. All interviewees mentioned risks associated to human activities which are sometimes linked to climate risks; hence, humanmade incidents were also included in the table.

Table 5. Result of thematic analysis.

\begin{tabular}{ccc}
\hline Themes & Sub-Themes & Nodes \\
\hline \multirow{2}{*}{ Baseline } & Efficiency & $\begin{array}{c}\text { Capacity factor } \\
\text { Efficiency } \\
\text { Peak time }\end{array}$ \\
\cline { 2 - 3 } & Maintenance & $\begin{array}{c}\text { Maintenance } \\
\text { Panel cleaning }\end{array}$ \\
\cline { 2 - 3 } & Weather & $\begin{array}{c}\text { Solar radiation } \\
\text { Weather condition }\end{array}$ \\
& Corporate social responsibility & $\begin{array}{c}\text { Corporate social responsibility } \\
\text { Local employment }\end{array}$ \\
\cline { 2 - 3 } Countermeasure & Firebreak & Firebreak \\
& Wet forest \\
\cline { 2 - 3 } & Flood-related actions & Canal cleaning \\
& & Dike construction \\
\hline
\end{tabular}


Table 5. Cont.

\begin{tabular}{|c|c|c|}
\hline Themes & Sub-Themes & Nodes \\
\hline \multirow{4}{*}{ Causes } & Flood and storm & $\begin{array}{l}\text { Dam break } \\
\text { Flooding } \\
\text { Tree falls } \\
\text { Tropical storm }\end{array}$ \\
\hline & Fire & Forest fire \\
\hline & Human-made & $\begin{array}{c}\text { Car accident } \\
\text { Damaged panel } \\
\text { Human-made incidents } \\
\text { Lawn mowing accident } \\
\text { Public resistance }\end{array}$ \\
\hline & Lightning & Lightning strike \\
\hline \multirow[t]{3}{*}{ Damage } & Flood & $\begin{array}{c}\text { Damage of flood } \\
\text { Damaged cables } \\
\text { Flood level } \\
\text { Flooded area } \\
\text { Water drainage } \\
\text { Water level } \\
\text { Waterlogged }\end{array}$ \\
\hline & Human-made & $\begin{array}{c}\text { Damage of human-made incidents } \\
\text { Damaged panel } \\
\text { Trip record }\end{array}$ \\
\hline & Lightning & Damage of lightning strike \\
\hline Result & Result & $\begin{array}{l}\text { Expected results of unimplemented } \\
\text { actions } \\
\text { Results of implemented actions } \\
\text { Success in implementation }\end{array}$ \\
\hline \multirow{4}{*}{ Location } & Condition & $\begin{array}{c}\text { Geographical condition } \\
\text { Land title deeds } \\
\text { Ownership } \\
\text { Site area } \\
\text { Site location } \\
\text { Solar radiation }\end{array}$ \\
\hline & Contract & $\begin{array}{c}\text { Feeder } \\
\text { Power purchase agreement }\end{array}$ \\
\hline & Justification of location & Justification of location \\
\hline & Preparation & Preparation of land \\
\hline
\end{tabular}

Table 6. Word counts of climate and human-made risks in the scripts of in-depth interviews.

\begin{tabular}{|c|c|c|c|c|c|c|}
\hline \multirow{2}{*}{ No. } & \multirow{2}{*}{ Risk } & \multicolumn{4}{|c|}{ Word Counts } & \multirow{2}{*}{$\begin{array}{c}\text { Total } \\
\text { Counts }\end{array}$} \\
\hline & & KS1 & KS2 & KS3 & KS4 & \\
\hline 1 & Flood & 1 & 19 & 6 & 9 & 35 \\
\hline 2 & Storm & 9 & 3 & 2 & 0 & 14 \\
\hline 3 & Forest fire & 3 & 0 & 2 & 1 & 6 \\
\hline 4 & Lightning & 0 & 5 & 5 & 1 & 11 \\
\hline 5 & Human-made & 5 & 9 & 3 & 4 & 21 \\
\hline
\end{tabular}

\subsubsection{Flood and Storm}

The analysis indicates that key sites experienced climatic events such as floods, generally due to extreme rainfall and storm. Since intensity of extreme climate event can potentially affect plant operation [88], KS2 calmly stated "The 2011 Thailand Flood was the biggest ever flood we have ever experienced." This is one of the technological or humanmade hazards rooted in increasing intensity of natural disasters, so-called natural hazards triggering technological disaster (NATECH) [89]. It is evident that extreme precipitation drove the flood which damaged the power plant [90]. The same informant further revealed the causes of the flood by saying "The cause of flood was exactly due to the low elevation 
of the plant." and "The reservoir (Ban Morasuap reservoir) was cracked and holed. It could not bear with enormous water body from heavy rain. I remembered it was a raging storm." According to literature, flat terrain is favorable for solar power plants [84]. For sites with slope or low elevation, there is a possibility of flood [86]. Awareness on necessity for land leveling and grading should be raised as it is suggested that development of solar power plant should be taking place outside flood risk area [86]. Not every enterprise realizes its importance, but KS3 described "Our executives and board members prioritized land leveling and grading; therefore, we raised the land level by $50 \mathrm{~cm}$." In the solar power plant located on high slope, extreme rainfall and tropical storm still can harm plant operation even after leveling the land, since heavy rain not only cause flood, but also waterlogged and landslides. To prevent the consequences, literature suggested agrivoltaic as a solution [55]. KS1 told "Water erosion made no damage to the panel nor mounting structure, but left holes on ground." KS1 added "Wind and storm as well. They didn't cause damages to our solar farm, but to the (electricity) authority's transmission lines. This affected the generation output." These informant's insights can be considered robust and comprehensive as they are supported by academic literature [91]. Heavy rain and tropical storms can lead to extensive flooding [43], bringing about severe damages to energy infrastructure and subsequently plant operation disruption [44]. KS2 stated "The panels and inverters were submerged and caused disruption of a two-day long and it took us two days to drain." and added "Due to the event, we stopped our system for a month before full recovery." Additionally, KS4 responded to the assumptions "There were windstorms occurred and trees fell upon transmission lines. This happened to another site under our responsibility." and "That tree falls caused the trip of the transmission line." Although some power plants were well-prepared, extreme rain fall incurs waterlogged [44]. KS3 stated "We were not able to drain out water since the rain was too heavy." In some cases, energy infrastructure and system components were not designed to bear with instantaneous and simultaneous floods [44]. Power generation systems could be disrupted. KS2 indicated "30 boxes (array junction box) were severely damaged, and it costed us approximately 3000 US dollars." and added "Over 15,480 PV panels were submerged. Unfortunately, only 4000 panels can be covered by insurance." Consequences from flooding was not only to the energy infrastructure but also transportation facilities such as road to power plants, which suspended plant operation and maintenance activities. KS4 added "During the season (rain), water overflowed the road (affecting the accessibility of the plant)."

To minimize consequences from floods, solar power plants implemented several climate adaptation countermeasures. Many means, concepts and guidelines were studied and developed covering a number of countermeasures, for example, project site selection [65], disaster risk management application, water level measurement [62], improvement of power system specifications, implementation of emergency response, construction of dikes, embankments, dams and reservoirs [61], land leveling [85], installation of concrete structure with bar for module mounting [85], installation of water-proofing equipment, upgrade of transmission sub-stations [62]. From the interviews, informants pledged "We do have budget for land grading." "It (budget) was included in the capital investment. (KS1)”, KS1 added "The wet forest consisting of vetiver grass will be planted on slope ground. It will help prevent landslide." and added "Soil compaction was done roughly. When it rained, the ground decayed and mounting structure was eroded." KS2 stated "In the past, there were embankments around the site." then "After the flood event, we decided to increase the level (of the embankment).". KS2 added "We also increase the mounting structure level up to $3 \mathrm{~m}$ and 30 array junction boxes was raised up to 1.2-1.5 m over the ground which took considerable period of time and caused additional investment." In the third and fourth key sites, climate adaptation countermeasures were adopted as well. KS3 stated "We built up dikes around plant border and drilled a well for water drainage." and KS4 "We elevated panel mounting structures over the water level." then "With the height of structure, we decided to attach the wires to the upper part of the structure which resulted in approximately $20 \%$ additional expenses, but the cost was acceptable." Given the attempts to avoid 
and/or minimize flood risks and consequences, additional expenses were required and should be made available to put the strategies in place [62]. Since these strategies are costly, they should be as practicable as possible without sacrificing the economic feasibility [92].

\subsubsection{Fire}

Due to climate change, extreme weather events caused severity frequency of the event is expected to increase [43], causing damage to solar infrastructure [93]. The closer solar power plant is located to dried forest, the higher the risk that the plant could be affected by forest fire. Informant reported that power plant sites were located nearby dried forest and in the area where locals light fires in forests for several purposes, for example, to make a living and animal hunts (accelerating germination of mushrooms, bamboo shoots and forcing animals from hideouts). KS1 reported "Fires can be easily observed in the area." However, KS1 declared no effects from forest fire since the fires were small and far from the site. Additionally, KS2 informed "Locals light fire from time to time." Based on finding from key sites, there was no fire-related hazards reported to create any damage and losses. Nevertheless, key sites were well-prepared and applied forest fire countermeasures to tackle with the hazard. By creating firebreak and surrounding the solar power plant with wet forests, KS1 believed that the strategies are practicable against forest fire. "The wet forest was costly. The number is about 4600 to 6100 US dollars for a 430-m long." However, this kind of risk is considered difficult to quantify, but can be avoided by consideration of plant's location at the first place [61].

\subsubsection{Lightning}

Depending on its location, literature indicated that energy infrastructure can be exposed to lightning, sometimes called atmospheric over-voltages, which is one of harmful natural events [45]. Lightning strikes can critically damage significant electric component of energy systems, leading to short-time power cut and disruption in plant operation [90] as well as failure in monitoring system. Informants reported unrecognized lightning strikes causing damages on the solar panels. For years that key sites under KS2 responsibility have experienced panel damage caused by this kind of natural events. KS2 reported "It (lighting) stroke in another branch of ours but didn't make serious damage." KS4 added "Since it (the site) is an open field, there were a few strikes yearly." then losses from the incidents were reported "To date, the damaged panels (from lightning strikes) were counted up to 100." by KS1. On the other hand, the informant's experience with lightning argued against literature that indicated that all devices in the power plant could be damaged by lightning strikes. KS2 claimed "Other equipment were damaged (by lightning strikes), but not PV panels." However, another key site faced lightning strikes on panels, inverters, and the monitoring system. KS3 pledged "The cause was mainly from surge issues, resulting in damage in monitoring system in damage. Direct hit from lightning may affect inverters and PV panels." KS3 added that lightning strikes had significant impact on inverter. "Another site under our responsibility were also damaged due to the issue (lightning). 30 of 600 inverters were severely damaged." This is strong evidence that support the importance of deployment of lightning protection system (LPS) which can prevent insulation breakdown [88]. However, inadequate protection against lightning may delay return of investment on power generation system [88]. Key sites indicated strategic ways to reduce the risk. KS2 stated "grounding and earthing were implemented in all structures to protect lightning." KS4 supported "We attached lighting conductors to the top of the mounting structure and the utility pole."

\subsubsection{Human-Made Incidents}

From the discussion with informants over several topics, it was found that humanmade actions are one of the crucial issues that should never be overlooked. Accidents derived from plant operation activities can damage critical parts of energy infrastructure [94]. In key sites, several human-derived issues were reported, and consequences were 
found. Starting from KS1, it was found that soil issue such as inadequate soil compaction is a reason that landslide and waterlogged occurred, as KS1 confirmed "Soil compaction was done roughly. When it rained, the ground decayed, and mounting structure was eroded." Additionally, photovoltaic panel with underconditioned quality control causes hotspots on the panel surface. These defects are technological failures that reduces output power [95]. This is not just a technical issue, but an inappropriate utilization of tools for periodic maintenance which can result in opportunity loss of power generation. Three key sites indicated that several panels were cracked due to lawn mowing activities. KS1, KS2, and KS3 reported "Lawn mowing was an issue" "At least 6-7 PV panels were damaged by the pebbles" "We were using razor blades. After that, we changed to trimmer lines." respectively. Changing to trimmer lines seems to be a good countermeasure to prevent pebbles from bouncing to panels. KS2 stated "For such activity, we needed to use the (trimmer) lines rather than blade." In addition, "We used machines in bigger area and put the cover on." Later, KS1 reported that cracked of flawed panels are not only caused by lawn mowing activities, but also occasion celebration events and animal hunts. Since solar power plants are often set up at location where local communities surround, fireworks, skyrocket, bullets from local activities such as New Year's Eve celebration (shooting at sky), and animal hunts spotted cracked panels. These incidents harm plant operating. KS3 confirmed "We didn't receive damages from such activities. However, there were skyrocket cases in other sites under our responsibility, especially in northeast." To assure safety, key sites approached communities and requested for awareness of safety and re-direction of fireworks, skyrocket, and bullets. The requests for cooperation were carried out and ended up successfully throughout community participation.

\subsection{Location Selection}

Thematic analysis revealed location selection as another important issue. There are three themes under this cluster, including site selection conditions, land preparation, and justification of location were highlighted, as illustrated in Table 5.

\subsubsection{Site Selection Conditions}

Site selection is indicated by many studies [54,82-86] as a crucial procedure for the development of a solar power plant. Several necessary criteria were identified and encouraged to be taken into account, for example, solar radiation, proximity to transmission line [96], weather pattern, land slope [92], land use, and flood-sensitive area [82]. Based on the analysis of in-depth interviews, it was indicated that geographical conditions were primary criteria in site selection to minimize high capital investment. It was reported that preferred conditions were flat terrain, proximity to transport infrastructure (road), flood-avoided areas, large areas with land deeds. KS1 reported that flat terrain prevents shading effect from adjacent panels. "Our site was located on flat terrain for the reason to prevent the shading (KS1)." KS2 pledged it is important to find sufficiently large area to accommodate the contracted capacity. For $1 \mathrm{MW}$, the site should be a minimum of 4 acres. It was indicated "This site comprised of 3 branches, and the (land) size is 80 acres." and "this branch was $8 \mathrm{MW}, 30$ acres." KS3 claimed that solar power plant site should prioritize access to transport infrastructure such as road which facilitates operation. The informant stated that "Our solar sites was next to major roads, since executives gave the priority to it." In addition, key site under KS4 responsibility aim for flood-avoided areas, since the available feeder were in flood-sensitive area. The informant claimed that "We took over most solar (power plant) sites from other enterprises." "We only picked one where flood cannot reach." On the other hand, "There were also other areas, where we can develop solar power plant, but it was difficult to reach out, since it was quite far away from roads and was essentially flooded area." 


\subsubsection{Land Preparation}

Since land slope can affect solar radiation and initial project costs [82], land preparation should be taken into account when deploying solar power plants. IRENA indicated absence of consensus regarding accepted percentage of slope [97]. KS1 indicated suitable area for solar requires land preparation. "We got the land prepared and graded. Trees in the site needed to be cut and removed (KS1)." and "we needed to flatten the surface of land as much as possible to make it suitable for installation of PV panels." This evidence aligned with literature's suggestion that steep slope of land is not preferable due to shadow projection [84]. Therefore, there is a need to facilitate land leveling, resulting in an increase in project cost. It was suggested that solar power plant sites should be installed on barren land, refraining agricultural or fertile areas [82]. However, with the land size requirements, land preparation must be conducted. "Sugar palm trees were cut and removed, and farm fields were backfilled with soil", KS2 spoke. In some cases, enterprises studied and experienced flood events in solar power plant sites. Land leveling was carried out even if the flood risk is small. KS3 informed that the strategy aimed to encounter unexpected events such as a flash flood. Ever since the launch of the site, it found no risks towards incidents from water. KS3 stated "Plan for land leveling was prepared since the initial stage." and "We needed to elevate it by $50 \mathrm{~cm}$ because it helped reduce the (flood) risks." KS4 was backfilled, but not leveled due to unaffordable investment and unworthiness within the time frame of contract license. KS4 informed "The site was farmland. We did grade but did not elevate due to high cost."

\subsection{Justification of Location}

All informants reported different reasons on justification of their site location. KS1 claimed that total available area required for development of a solar power plant was large. The selected location was less steep and require smaller land preparation budget compared to other areas. KS1 informed "This area is the most suitable land for grading. Other areas are high and with steep slope. Indeed, land preparation would be more costly." In case of KS2, the justification of site location mainly involved availability of the transmission line and the sub-station. The selected area is able to install adequate panels and other equipment according to the power purchase agreement and contract license, as well as the voltage level is acceptable when compared to other large available lands. KS2 claimed "Transmission lines were available and able to support 24 MW output to sub-station." KS3 reported in the same direction to KS2 where power purchase agreement and contract license played a critical role in site location. With limited choices of areas, KS3 reported difficulty in location search. KS3 described "Power purchase agreement would indicate location where we can invest on solar power plants." and "due to that (agreement) we started to seek for a suitable land, and some were recommended by agencies." Lastly, KS4's solar power plant prioritized flood sensitivity and solar radiation during the location selection. Still, available area is limited by the conditions in the contract. KS4 explained "Since the agreement determined locations in the city, our site here was the most suitable to set up a power plant. Flood sensitivity and solar radiation were indicators for site selection."

\section{Discussion}

\subsection{Key Insights from Thematic Analysis}

\subsubsection{Climate Risks and Countermeasures}

The thematic analysis above revealed climate risks associated with solar power plants, particularly flood and storm risk, fire risk, and lightning risk, and the countermeasures that have been taken to prevent or alleviate the risks, as shown in Figure 3. To prioritize the climate-related risks of solar power plants based on the analysis, word frequencies of each risk are summarized in Table 6. It could be observed that "flood" is the only natural hazard that appears in all interviews and has the highest counts among the keywords, followed by storms, lightning, and fires, respectively. This aligns well with past quantitative studies that indicated that floods and storms are the major natural hazards affecting countries 
around the world [42], including Thailand [41], and they are the main reasons to power outages [98]. Thailand is listed among countries where power generation has the highest exposure to natural hazards causing high annual damage and generation losses [42]. It seems natural that the power plants are concerned about flooding since the 2011 Thailand Floods made Thailand the only middle-income country that is listed in the top 10 countries most affected by natural disaster from 2000 to 2019 [99]. Precipitation projections also indicated that the intensity of daily rainfall events will be higher in the future, in Bangkok Metropolitan [36], in Thailand [37], and in Asia [38], which leads to more frequent floods with potentially longer duration [100]. To make things worse, climate change will shorten the return period of a flood similar to the 2011 Thailand Floods [40] of which the return period is expected to be 10-20 years [39]. These quantitative flood and storm risks back up the fact that all interviewees recognize these risks and make considerable efforts to address them.

Based on the thematic analysis results, consequences to the power plants vary with size, location and existing countermeasures, starting from submersion of panels, inverters, and/or other apparatus [44], to soil erosion at the basement of the structure of the solar panels. Storms can also topple the trees or rip the branches near the transmission line [101], causing the outage of the electricity supply system which stops the power plant's sales of electricity. Some owners build dikes or fill the land to avoid being flooded, some decide to leave with floods by increasing the height of the solar panel structure by 1-2 $\mathrm{m}$. Soil compaction and agrivoltaic are the two available options to address the issue of soil erosion at the basement of the structure by helping with the soil retention [102]. Lightning which usually comes with storm is also another concern of the power stations. It may lead to insulation breakdown, grounding potential rise, and panel and/or inverter destruction [45]. Lightning conductors are thus installed at many power plants to minimize the damage from lightning. Though there have not been any fire events in all four interviewed key sites, three of them possess or have considered installation of firebreaks since there are lit fires during dry season within the proximity of the power plants. Even though the interview was centered around climate hazards, it can be seen from Table 6 that most interviewees touched upon human-made incidents, e.g., fireworks, skyrockets, and bullets. Most sites successfully mitigate consequences from these events by building good relationships with surrounding communities through corporate social responsibility (CSR) activities or employment of locals.

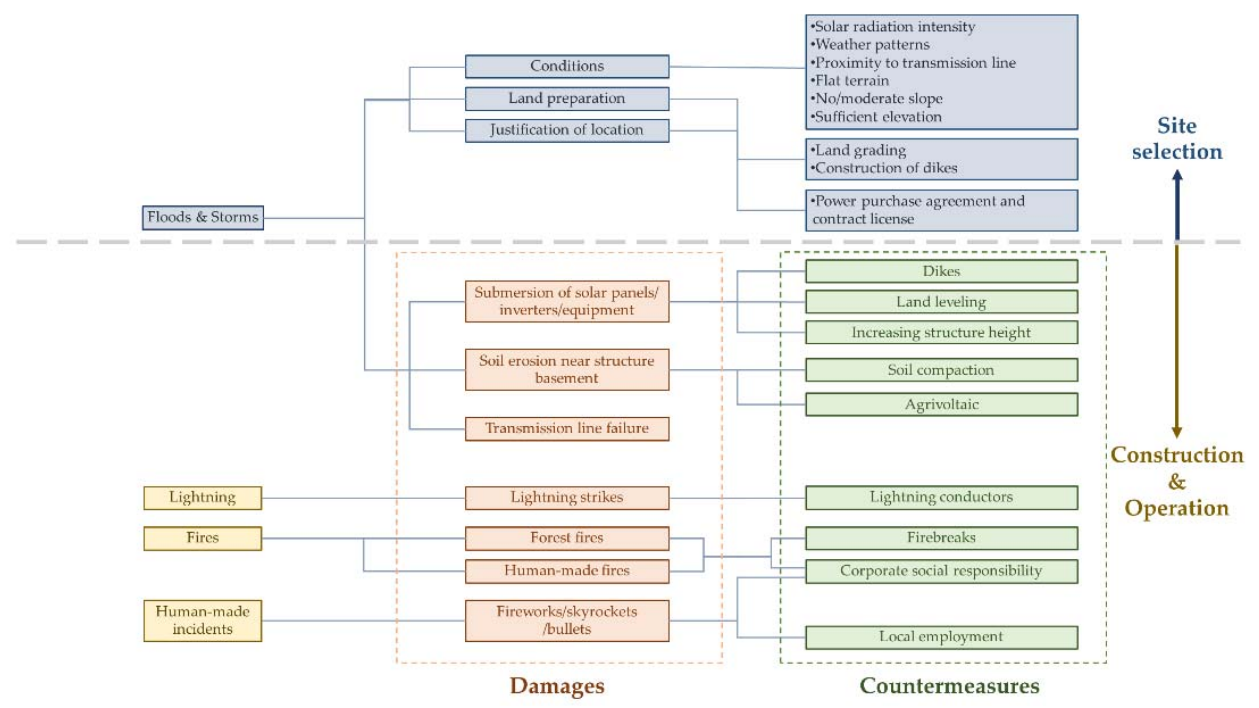

Figure 3. Key insights from thematic analysis on climate risks, countermeasures, and points of consideration during location selection. 


\subsubsection{Relationship between Climate Risks and Site Selection}

The other important part of Figure 3 covers the relationship between climate risks and site selection. The results from the thematic analysis indicated that climate adaptability of solar power plants also depend on the site selection which is the phase before the construction of the plants. Apart from solar radiation intensity [59], average temperature [103], weather patterns, and proximity to transmission line [104], which are the main points of consideration for most power plants, there are several more aspects based on past studies that limit the possible sites for solar power plants, especially large-scale solar farms. Considering economic factors such as land cost and construction cost is unavoidable [105], land with slopes which is generally unused and cost saving is preferable at first sight [106]. However, land grading and construction can significantly increase capital investment. Hence, construction of large-scale solar power plant often required vast flat land with low slope, since high slopes make it difficult for logistics, constriction, and the right angle of panels [107]. Moreover, land surface temperature was indicated as important since it prevents energy loss derived from heat under PV panels [59]. It is sometimes argued that climatic conditions are crucial and can affect the power plant performance [83]. These conditions for site selection perfectly resonate with the insights from the thematic analysis. While others focused on climatic, social and economic factors for site selection, a few studies suggested strategic application of climate-proofing countermeasures to address natural risks, e.g., embankments, dikes, and reservoirs. However, these countermeasures significantly increase the capital investment. Some power plant owners may end up selecting climate-vulnerable sites and taking the risk of being flooded during severe flood events without implementing any countermeasures. Another important element that the enterprise use to justify the site selection is the conditions of power purchasing in Thailand. Solar power plants can only be installed where the feeders are available. Auction is used to choose the companies that propose the lowest selling prices and give them the right to build the power plants. This scheme prevents enterprises from investing on site selection before being awarded. Furthermore, the enterprises should plan carefully to start operating before the scheduled commercial operation date (SCOD) in order not to be penalized. This significantly shortens the period of consideration for site selection process.

\subsection{Scenario Development for Consideration of Climate Adaptation}

Figure 3 shows four different scenarios generally considered during the discussion on feasibility of climate-proofing countermeasures [108]. They are basically the combination of scenarios with/without climate change and with/without climate proofing countermeasure(s). Climate change is expected to increase the frequency and the intensity of climate events, e.g., high precipitation, storms, drought [42]. In case of solar power plants, this can potentially disrupt the electricity production or cause damages to equipment. Most climate-proofing countermeasures, whether hard or soft, result in additional expenses. Most assessment has been focusing on how to ensure economic feasibility of the countermeasures [108-110], and how to facilitate the climate-proofing investment [111]. However, as can be seen from the results from thematic analysis, this study focuses more on the details of the actual effects from climate change on solar power plants and the actual or planned countermeasures in order to derive policy recommendation to accelerate climate-proofing investment.

Scenarios without climate change normally serves as a baseline case for economic analysis. However, the Intergovernmental Panel on Climate Change (IPCC) claimed with high confidence that climate change is real [7]; hence, there is no need to consider the case where climate change does not happen. As discussed above, climate change will increase the precipitation intensity [36-38], increase the frequency and the severity [100], and shorten the returning period of floods and storms [40]. This study will focus on the right-hand side of Figure 4 which compare the cases that climate change happens with and without climate-proofing investment. For the scenario without climate-proofing countermeasures, the capital investment will not be different from current situation. Enterprises would still 
focus on solar radiation intensity, average temperature, weather patterns, and proximity to transmission line during site selection. They would spend extensive money on site preparation and climate-proofing countermeasures during power plant construction and operation, only if one of the climate events severely affected one of their power plants in the past, or other facilities in the proximity. Climate change will result in power plants being more frequently affected by climate incidents, especially floods and storms, and consequently larger total expenditure throughout the lifecycle in most power plants [42]. When the solar energy share gradually increases to meet the NDC, the number of power plants being out of order during and after disasters will escalate. This poses a great impact on energy security of the country [112]. Consequently, government will need to spare additional budget for disaster relief and for recovery of solar power plants. On the other hand, if all climate-proofing countermeasures are implemented, the capital investment will be very high, and the cost to operate and maintain the power plants will also be significantly higher than the former scenario. However, as most cost-benefit analyses of investment on climate proofing show that the benefit-cost ratio of most countermeasures is larger than $1[42,113]$, the aforementioned investment should be much smaller than their total benefits in reducing expenses on climate-derived damages of affected stakeholders. The main issue is that the paying parties and the benefitting parties may not be the same.

Both extreme scenarios will never happen in the future. In reality, government policies supporting climate adaptation of energy infrastructure and those unintentionally discouraging climate-proofing investment, as well as the responses of private sector to those policies will create a spectrum of possible futures between the two scenarios. From the triangulation of observations, interviews, and literatures, it was found that the statements of interviewees align well with the observations by the interviewers and the findings from past literatures and other quantitative studies. Effects from climate incidents, especially floods and storms, on solar power plants are increasing due to climate change. In addition, selection of suitable location will be even more difficult when the number of solar power plants rises, which means climate adaptation strategies will play a more significant role in the future. Therefore, policies in the domain of solar energy should be designed in order to move closer to the scenario with climate-proofing measures.
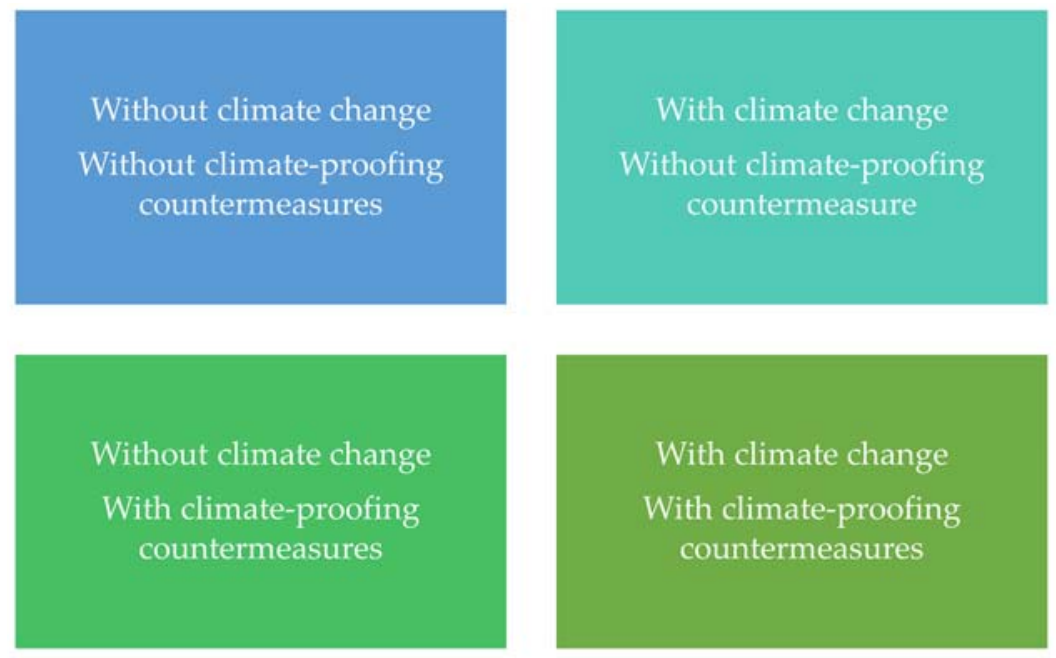

Figure 4. General scenarios for discussion on climate adaptation.

\subsection{Policy Recommendation for Facilitation of Solar Energy Large-Scale Deployment in Thailand}

\subsubsection{Support for Implementation of Climate-Proofing Countermeasures}

It is evident from the previous section that climate risks identified by past quantitative risk assessments exist, and climate proofing countermeasures are needed to increase the climate adaptive capacity of the solar power plants. It is commonly known that policy support from national and local governments are inevitable to the promotion of these 
climate-proofing countermeasures [114]. Policy support can be in terms of legislation or regulations that ease the implementation of the countermeasures [115], or financial incentives [116]. For example, the government can set a rule that the elevation of the solar power plant sites should be at least at the same level as the adjacent roads. Financial incentives can be in the forms of subsidy, tax exemption or no interest loan for a large-scale investment on climate adaptation, e.g., land grading, firebreak construction. Financial disincentives, such as penalties for solar power plants that cannot recover within the specified period after a climate event. If these kinds of policy support exist, KS4 would have undergone countermeasures to prevent waterlogged during rainy season. Since mobilizing finance is one of the goals of COP26 [1], international financial support for climate-proofing investment projects can also be expected to backup financial incentivization of the Thai government $[117,118]$.

\subsubsection{Preparation for Fast Recovery after a Nationwide Disaster}

Aforementioned policy support would be sufficient for furnishing solar power plants with climate-proofing countermeasures in order to adapt to climate change during the first few years of the long-term energy plan. However, the frequency and the severity of climate events will eventually increase with time, and the number of solar power plants will significantly grow according to the new National Energy Plan [16]. If the government is not able to secure extensive budget to support climate adaptive capacity building of the solar power plants, future sites that meet climate resilience requirements would become progressively limited. More and more power plants will fail to withstand climate incidents, and a number of power plants could be out of order simultaneously during nationwide disasters. National energy security would be disrupted during such disasters. Enterprises, with adequate support from national and local governments, would need to secure more budget for emergency preparedness and response in order to maintain the national electricity generation capacity during a severe climate event. On the other hand, more climate-proofing investment has to be made to increase the level of resilience of the vulnerable sites. In this regard, energy storages can increase the supply reliability by storing the generated electricity for emergency use [91], though they were not touched upon by any of the interviewees, potentially due to their current economic unfeasibility

\subsubsection{Reconsideration of Conditions for Power Purchasing}

Thailand adopts auction as the main scheme to award the contract to the bidders that are among those who proposed the lowest Feed-in-Tariff (FiT) rate for solar power wholesales to the electricity authorities [119]. This is beneficial to the consumers since the scheme can theoretically minimize the electricity unit price [120]. However, as stated above, the scheme unexpectedly hinders site selection process. Enterprises will not start seeking for the land if they are not certain that they will be awarded a solar power plant contract. On the other hand, the government wants to follow its plan of increasing the share of solar energy accordingly and needs the power plants to enter their commercial operation as soon as possible. Moreover, solar power plants require large flat terrain with adequate elevation, which significantly limits the land availability. This coincidence results in a very limited timeframe for site selection and makes many existing sites vulnerable to climate incidents. Changing from auction to fix rate power purchase is also not a good idea since it will put more burden on the shoulder of the public. There are three possible ways to ensure climate adaptability of the sites without significantly altering the bidding process.

1. Give priority to bidders that own or have a prospect to own a climate-resilient site. These bidders can be considered first or get a better electricity selling price.

2. If the winning bidders provide sufficient evidence to prove the difficulty in finding a climate-resilient site, the SCOD can be delayed by a certain period of time.

3. The Energy Regulatory Commission can coordinate with Department of Land to produce a map that indicates the areas that are suitable for solar power plants. The team can also assist the winning bidders with land mobilization. 
Further study should be conducted to optimize the solutions for this issue. At this stage, it is important to recognize the influence of conditions for power purchasing on the climate adaptability of the solar power plants and the necessity to seek for good solutions in order to achieve climate-resilient solar-based electricity generation

\section{Conclusions}

This study captured climate-related risks associated to solar power plants in Thailand and climate-proofing countermeasures that were taken or planned, using thematic analysis. The findings of current study are derived from qualitative methodology capturing human insights and experience towards climatic incidents which could be difficult to obtain from quantitative methodology. The thematic analysis pointed out that floods and storms were perceived as major climate events affecting solar power plants in Thailand, followed by lightning and fires. Floods and storms could cause submersion of solar panels, inverters or equipment, soil erosion near structure basement of solar panels, and transmission line failure. Several countermeasures were taken, including dike construction, land leveling, increasing structure height, soil compaction, and agrivoltaic. Installation of firebreaks and corporate social responsibility activities helped alleviate fire risk, and lightning conductors were installed in many power plants to avoid lightning strikes. Flood and storm risks could also significantly affect site selection. The necessity of the land to be flat with no slope and with sufficient elevation in order to withstand future floods makes it difficult to find suitable sites within the provided timeframe. The sites might need to undergo land leveling or dike construction. It was also found that the auction scheme and the conditions under power purchase agreement could hinder the optimization of site selection.

Results from thematic analysis were used to develop two scenarios to consider climate adaptation of solar power plants: scenario without climate-proofing investment and scenario with climate proofing investment. It was recognized that possible future is somewhere in between the two scenarios, and that it is necessary get as close as possible to the latter scenario. Following recommendations to facilitate solar energy large-scale deployment were then derived from the scenarios.

1. National and local government should continue to provide policy support to solar power plant for climate-proofing investment in terms of enabling legislation or regulations, or financial incentives.

2. To accommodate climate events and the number of solar power plants that increase with time, enterprises, with adequate support from national and local governments, need to secure sufficient budget for fast recovery after severe climate incidents, especially nationwide disasters.

3. Since the current power purchasing conditions significantly affect the site selection process and consequently the climate adaptability of the solar power plants, measures must be taken to facilitate selection of climate-resilient sites by improving conditions of power purchase agreement or assisting winning bidders in enhancing climate adaptability of their sites.

The study indicated points of consideration from climate adaptation viewpoint that should be included in the long-term energy planning, apart from climate mitigation, i.e., greenhouse gas emission reduction. Significant increase in electricity generation capacity of solar energy in order to meet Thailand's updated NDC would result in more climate-vulnerable sites of solar power plants. If climate-proofing countermeasures are not appropriately and sufficiently implemented, the overall climate risks of all stakeholders would increase bringing about decrease in the power plants' climate adaptability. This confirms the necessity of considering both climate mitigation and climate adaptation during long-term energy planning. In addition, as renewable energy auctions which basically give priority to low electricity selling price can be an important reason of climate inadaptability of the solar power plants, policymakers should place more importance on the consideration of climate adaptive capacity of the power plants during the auctions 
and encourage the bidders to find climate-resilient sites or implement countermeasures to enhance the resilience of their solar power plant sites.

Though the study observed 35 solar power plants and interviewed only four of them, the power plants were carefully selected to cover power plants with different installed capacities scattered in all regions of Thailand. This ensures that the insights obtained from the study would be useful for most existing and future solar power plants in Thailand, and the recommendation on careful consideration of climate adaptability during site selection would be particularly helpful for countries employing renewable energy auctions.

Author Contributions: Conceptualization, K.S., P.J. and N.C.; methodology, P.J. and K.S.; validation, P.J.; formal analysis, P.J. and K.S.; investigation, K.S. and P.J.; resources, K.S. and P.J.; data curation, P.J.; writing —original draft preparation, K.S. and P.J.; writing—review and editing, K.S. and P.J.; visualization, K.S. and P.J.; supervision, N.C. and K.S.; project administration, K.S.; funding acquisition, N.C. All authors have read and agreed to the published version of the manuscript.

Funding: This research received no external funding.

Institutional Review Board Statement: Not applicable.

Informed Consent Statement: Informed verbal consent was obtained from all subjects involved in the study.

Acknowledgments: The authors would like to acknowledge solar power plant owners and operators who kindly cooperated with our self-administered observation and in-depth interviews, and thank our teammates, particularly Khemrath Vithean and Kampanat Thapmanee, who helped with figures and references.

Conflicts of Interest: The authors declare no conflict of interest.

\section{References}

1. UNFCCC. COP26 Explained; UNFCCC: Bonn, Germany, 2021.

2. UNFCCC. Climate Neutral Now Guidelines for Participation; UNFCCC: Bonn, Germany, 2021.

3. UN. Kyoto Protocol to the United Nations Framework Convention on Climate Change; UN: New York, NY, USA, 1998.

4. UN. Adoption of Paris Agreement; UN: New York, NY, USA, 2015.

5. UK Government. United Kingdom of Great Britain and Northern Ireland's Nationally Determined Contribution; UK Government: London, UK, 2020.

6. EU. Update of the NDC of the European Union and its Member States; EU: Berlin, Germany, 2020.

7. Allen, M.; Dube, O.; Solecki, W.; Aragón-Durand, F.; Cramer, W.; Humphreys, S.; Kainuma, M.; Kala, J.; Mahowald, N.; Mulugetta, Y. Global Warming of $1.5^{\circ} \mathrm{C}$. an IPCC Special Report on the Impacts of Global Warming of $1.5^{\circ} \mathrm{C}$ above Pre-Industrial Levels and Related Global Greenhouse Gas Emission Pathways, in the Context of Strengthening the Global Response to the Threat of Climate Change, Sustainable Development, and Efforts to Eradicate Poverty; IPCC: Geneva, Switzerland, 2018.

8. UNDP. UN Secretary-General Issues New Global Roadmap to Secure Clean Energy Access for All by 2030 and Net Zero Emissions by 2050; UNDP: New York, NY, USA, 2021.

9. UNFCCC. Thailand's Updated Nationally Determinded Contribution; UNFCCC: New York, NY, USA, 2020.

10. MFA. The Prime Minister Participated in the World Leaders Summit during the 26th United Nations Framework Convention on Climate Change Conference of the Parties (UNFCCC COP26) in Glasgow, United Kingdom. Available online: https:/ / www.mfa. go.th/en/content/cop26-glasgow? cate=5d5bcb4e15e39c306000683c (accessed on 7 December 2021).

11. Edenhofer, O.; Pichs-Madruga, R.; Sokona, Y.; Farahani, E.; Kadner, S.; Seyboth, K.; Adler, A.; Baum, I.; Brunner, S.; Eickemeier, P. Climate Change 2014: Mitigation of Climate Change. Working Group III Contribution to the Fifth Assessment Report of the Intergovernmental Panel on Climate Change; IPCC: Geneva, Switzerland, 2014.

12. IRENA. Renewable Power Generation Costs 2020; IRENA: Abu Dhabi, United Arab Emirates, 2021.

13. APERC. APEC Energy Overview 2021; APERC: Tokyo, Japan, 2021.

14. APAEC. ASEAN Plan of Action for Energy Cooperation (APAEC) Phase II: 2021-2025; APAEC: Jakarta, Indonesia, 2020.

15. Thailand Government. Mid-Century, Long-Term Low Greenhouse Gas Emission Development Strategy; Thailand Government: Bangkok, Thailand, 2021.

16. EPPO. National Energy Plan. Available online: http://www.eppo.go.th/epposite/index.php/th/petroleum/oil/link-doeb/ item/17093-nep (accessed on 7 December 2021).

17. IRENA, J. Benchmarking Scenario Comparisons: Key Indicators for the Clean Energy Transition; IRENA: Abu Dhabi, United Arab Emirates, 2021.

18. Gielen, D.; Boshell, F.; Saygin, D.; Bazilian, M.D.; Wagner, N.; Gorini, R. The role of renewable energy in the global energy transformation. Energy Strategy Rev. 2019, 24, 38-50. [CrossRef] 
19. Oree, V.; Hassen, S.Z.S.; Fleming, P.J. Generation expansion planning optimisation with renewable energy integration: A review. Renew. Sust. Energy Rev. 2017, 69, 790-803. [CrossRef]

20. Panos, E.; Kober, T.; Wokaun, A. Long term evaluation of electric storage technologies vs alternative flexibility options for the Swiss energy system. Appl. Energy 2019, 252, 113470. [CrossRef]

21. Hong, J.H.; Kim, J.; Son, W.; Shin, H.; Kim, N.; Lee, W.K.; Kim, J. Long-term energy strategy scenarios for South Korea: Transition to a sustainable energy system. Energy Policy 2019, 127, 425-437. [CrossRef]

22. Ouedraogo, N.S. Africa energy future: Alternative scenarios and their implications for sustainable development strategies. Energy Policy 2017, 106, 457-471. [CrossRef]

23. Mohsin, M.; Kamran, H.W.; Nawaz, M.A.; Hussain, M.S.; Dahri, A.S. Assessing the impact of transition from nonrenewable to renewable energy consumption on economic growth-environmental nexus from developing Asian economies. J. Environ. Manag. 2021, 284, 111999. [CrossRef]

24. Chaichaloempreecha, A.; Chunark, P.; Limmeechokchai, B. Assessment of Thailand's Energy Policy on CO2 Emissions: Implication of National Energy Plans to Achieve NDC Target. Int. Energy J. 2019, 19, 47-60.

25. UN. Transforming Our World: The 2030 Agenda for Sustainable Development; UN: New York, NY, USA, 2015.

26. UN. The Sustainable Development Goals Report 2021; UN: New York, NY, USA, 2021.

27. Fu, G.; Wilkinson, S.; Dawson, R.J.; Fowler, H.J.; Kilsby, C.; Panteli, M.; Mancarella, P. Integrated approach to assess the resilience of future electricity infrastructure networks to climate hazards. IEEE Syst. J. 2017, 12, 3169-3180. [CrossRef]

28. Miara, A.; Cohen, S.M.; Macknick, J.; Vorosmarty, C.J.; Corsi, F.; Sun, Y.N.; Tidwell, V.C.; Newmark, R.; Fekete, B.M. Climate-Water Adaptation for Future US Electricity Infrastructure. Environ. Sci. Technol. 2019, 53, 14029-14040. [CrossRef]

29. Binder, C.R.; Muhlemeier, S.; Wyss, R. An Indicator-Based Approach for Analyzing the Resilience of Transitions for Energy Regions. Part I: Theoretical and Conceptual Considerations. Energies 2017, 10, 36. [CrossRef]

30. EPPO. Thailand Power Development Plan 2018-2037 (PDP2018); EPPO: Luxembourg, 2019.

31. MONRE. Thailand's National Adaptation Plan. Available online: https://datacenter.deqp.go.th/media/881465/th-nationaladaptaion-plan-concept-and-progress.pdf (accessed on 7 December 2021).

32. MOE. Modelling results for five scenarios for the evaluation of expected CO2 emission. In Proceedings of the Meeting on Thailand's Greenhouse Gas Emission Reduction Framework for Energy Sector, Bangkok, Thailand, 4 June 2021.

33. Chaianong, A.; Pharino, C. Outlook and challenges for promoting solar photovoltaic rooftops in Thailand. Renew. Sust. Energy Rev. 2015, 48, 356-372. [CrossRef]

34. Chingulpitak, S.; Wongwises, S. Critical review of the current status of wind energy in Thailand. Renew. Sust. Energy Rev. 2014, 31, 312-318. [CrossRef]

35. Lorenczik, S.; Kim, S.; Wanner, B.; Bermudez Menendez, J.M.; Remme, U.; Hasegawa, T.; Keppler, J.H.; Mir, L.; Sousa, G.; Berthelemy, M. Projected Costs of Generating Electricity, 2020 ed.; Organisation for Economic Co-Operation and Development: Paris, France, 2020.

36. Cooper, R.T. Projection of future precipitation extremes across the Bangkok Metropolitan Region. Heliyon 2019, 5, e01678. [CrossRef]

37. Amnuaylojaroen, T. Projection of the precipitation extremes in thailand under climate change scenario RCP8. 5. Front. Environ. Sci. 2021, 1-344. [CrossRef]

38. Westra, S.; Fowler, H.; Evans, J.; Alexander, L.; Berg, P.; Johnson, F.; Kendon, E.; Lenderink, G.; Roberts, N. Future changes to the intensity and frequency of short-duration extreme rainfall. Rev. Geophys. 2014, 52, 522-555. [CrossRef]

39. Gale, E.L.; Saunders, M.A. The 2011 Thailand flood: Climate causes and return periods. Weather 2013, 68, 233-237. [CrossRef]

40. Paltan, H.; Allen, M.; Haustein, K.; Fuldauer, L.; Dadson, S. Global implications of 1.5 C and $2 \mathrm{C}$ warmer worlds on extreme river flows. Environ. Res. Lett. 2018, 13, 094003. [CrossRef]

41. UNDRR. Disaster Risk Reduction in Thailand: Status Report 2020; UNDRR: Geneva, Switzerland, 2020.

42. Hallegatte, S.; Rentschler, J.; Rozenberg, J. Lifelines: The Resilient Infrastructure Opportunity; World Bank Publications: Washington, DC, USA, 2019.

43. Cronin, J.; Anandarajah, G.; Dessens, O. Climate change impacts on the energy system: A review of trends and gaps. Clim. Change 2018, 151, 79-93. [CrossRef]

44. Shiradkar, N. Reliability and safety issues observed in flood affected PV power plants and strategies to mitigate the damage in future. In Proceedings of the 2019 IEEE 46th Photovoltaic Specialists Conference (PVSC), Chicago, IL, USA, 16-21 June 2019; pp. 3097-3102.

45. Damianaki, K.; Christodoulou, C.A.; Kokalis, C.-C.A.; Kyritsis, A.; Ellinas, E.D.; Vita, V.; Gonos, I.F. Lightning protection of photovoltaic systems: Computation of the developed potentials. Appl. Sci. 2021, 11, 337. [CrossRef]

46. Phasha, T.; Aderemi, B.; Chowdhury, S.; Olwal, T.; Abu-Mahfouz, A. Design strategies of an off-grid solar PV plant for office buildings: A case study of Johannesburg. In Proceedings of the 2018 IEEE PES/IAS PowerAfrica, Cape Town, South Africa, 26-29 June 2018; pp. 722-727.

47. Cavanini, L.; Ciabattoni, L.; Ferracuti, F.; Ippoliti, G.; Longhi, S. Microgrid sizing via profit maximization: A population based optimization approach. In Proceedings of the 2016 IEEE 14th International Conference on Industrial Informatics (INDIN), Poitiers, France, 18-21 July 2016; pp. 663-668. 
48. Ciabattoni, L.; Ferracuti, F.; Ippoliti, G.; Longhi, S. Artificial bee colonies based optimal sizing of microgrid components: A profit maximization approach. In Proceedings of the 2016 IEEE Congress on Evolutionary Computation (CEC), Vancouver, BC, Canada, 24-29 July 2016; pp. 2036-2042.

49. Savic, N.; Katic, V.; Dumnic, B.; Milicevic, D.; Corba, Z.; Katic, N. Cost-benefit analysis of the application of a distributed energy sources in the university campus microgrid proposal. In Proceedings of the IEEE EUROCON 2019-18th International Conference on Smart Technologies, Novi Sad, Serbia, 1-4 July 2019; pp. 1-6.

50. Benis, K.; Turan, I.; Reinhart, C.; Ferrão, P. Putting rooftops to use-A Cost-Benefit Analysis of food production vs. energy generation under Mediterranean climates. Cities 2018, 78, 166-179. [CrossRef]

51. Sandelowski, M. Using qualitative research. Qual. Health Res. 2004, 14, 1366-1386. [CrossRef] [PubMed]

52. Rosenthal, M. Qualitative research methods: Why, when, and how to conduct interviews and focus groups in pharmacy research. Curr. Pharm. Teach. Learn. 2016, 8, 509-516. [CrossRef]

53. Attride-Stirling, J. Thematic networks: An analytic tool for qualitative research. Qual. Res. 2001, 1, 385-405. [CrossRef]

54. Georgiou, A.; Skarlatos, D. Optimal site selection for sitting a solar park using multi-criteria decision analysis and geographical information systems. Geosci. Instrum. Methods Data Syst. 2016, 5, 321-332. [CrossRef]

55. Faizi, M.A.; Sandipkumar, V.M.; Verma, A.; Jain, V. Design and optimization of solar photovoltaic power plant in case of agrivoltaics. In Recent Trends in Materials and Devices; Springer: Cham, Switzerland, 2020; pp. 59-69.

56. Thanarak, P.; Chiramakara, T. GHG emission and cost performance of life cycle energy on agricultural land used for photovoltaic power plant. Int. J. Energy Econ. Policy 2019, 9, 156-165.

57. Merrouni, A.A.; Elalaoui, F.E.; Mezrhab, A.; Mezrhab, A.; Ghennioui, A. Large scale PV sites selection by combining GIS and Analytical Hierarchy Process. Case study: Eastern Morocco. Renew. Energy 2018, 119, 863-873. [CrossRef]

58. Ong, S.; Campbell, C.; Denholm, P.; Margolis, R.; Heath, G. Land-Use Requirements for Solar Power Plants in the United States; National Renewable Energy Lab. (NREL): Golden, CO, USA, 2013.

59. Türk, S.; Koç, A.; Şahin, G. Multi-criteria of PV solar site selection problem using GIS-intuitionistic fuzzy based approach in Erzurum province/Turkey. Sci. Rep. 2021, 11, 5034. [CrossRef]

60. Solaun, K.; Cerdá, E. Climate change impacts on renewable energy generation. A review of quantitative projections. Renew. Sustain. Energy Rev. 2019, 116, 109415. [CrossRef]

61. Makky, M.; Kalash, H. Potential Risks of Climate Change on Thermal Power Plants. 2013. Available online: https://www. researchgate.net/publication/236174007 (accessed on 7 December 2021).

62. Crook, J.A.; Jones, L.A.; Forster, P.M.; Crook, R. Climate change impacts on future photovoltaic and concentrated solar power energy output. Energy Environ. Sci. 2011, 4, 3101-3109. [CrossRef]

63. ADB. Guidelines For Climate Proofing Investment In The Energy Sector; ADB: Manila, Philippines, 2013.

64. IRENA. Overcoming Barriers to Authorizing Renewable Power Plants and Infrastructure; IRENA: Abu Dhabi, United Arab Emirates, 2013.

65. Wu, Y.; Deng, Z.; Tao, Y.; Wang, L.; Liu, F.; Zhou, J. Site selection decision framework for photovoltaic hydrogen production project using BWM-CRITIC-MABAC: A case study in Zhangjiakou. J. Clean. Prod. 2021, 324, 129233. [CrossRef]

66. Roberts, K.; Dowell, A.; Nie, J.-B. Attempting rigour and replicability in thematic analysis of qualitative research data; a case study of codebook development. BMC Med. Res. Methodol. 2019, 19, 66. [CrossRef] [PubMed]

67. Maswabi, M.G.; Chun, J.; Chung, S.-Y. Barriers to energy transition: A case of Botswana. Energy Policy 2021, $158,112514$. [CrossRef]

68. Moorthy, K.; Patwa, N.; Gupta, Y. Breaking barriers in deployment of renewable energy. Heliyon 2019, 5, e01166.

69. De Desarrollo, B.A. Climate Proofing: A Risk-Based Approach to Adaptation; ADB: Manila, Philippines, 2005.

70. UN. Climate Proofing Toolkit: For Basic Urban Infrastructure with a Focus on Water and Sanitation; UN: New York, NY, USA, 2021.

71. Williamson, L.E.; Connor, H.; Moezzi, M. Climate-Proofing Energy Systems; Helio International: Paris France, 2009.

72. Sirasoontorn, P.; Koomsup, P. Energy Transition in Thailand: Challenges and Opportunities; Friedrich-Ebert-Stiftung Thailand Office: Bangkok, Thailand, 2017.

73. WHO. Floods: Climate Change and Adaptation Strategies for Human Health: Report on a WHO Meeting: London, United Kingdom, 30 June-2 July 2002; World Health Organization, Regional Office for Europe: København, Denmark, 2002.

74. UN. Guidelines for Climate Change Proofing in UNDP Projects and Programmes in Armenia; UN: New York, NY, USA, 2009.

75. UN. Theme Report on Energy Access towards the Achievement of SDG 7 and Net-Zero Emissions; UN: New York, NY, USA, 2021.

76. Braun, V.; Clarke, V. Using thematic analysis in psychology. Qual. Res. Psychol. 2006, 3, 77-101. [CrossRef]

77. Maguire, M.; Delahunt, B. Doing a thematic analysis: A practical, step-by-step guide for learning and teaching scholars. Irel. J. High. Educ. 2017, 9, 3.

78. Lo, Y.-C.; Janta, P. Resident's perspective on developing community-based tourism-A qualitative study of Muen Ngoen Kong Community, Chiang Mai, Thailand. Front. Psychol. 2020, 11, 1493. [CrossRef]

79. Lincoln, Y.S.; Guba, E.G. Naturalistic Inquiry; Sage: Thousand Oaks, CA, USA, 1985.

80. Nowell, L.S.; Norris, J.M.; White, D.E.; Moules, N.J. Thematic analysis: Striving to meet the trustworthiness criteria. Int. J. Qual. Methods 2017, 16, 1609406917733847. [CrossRef]

81. Guion, L.A.; Diehl, D.C.; McDonald, D. Triangulation: Establishing the validity of qualitative studies. Edis 2011, 2011, 3. [CrossRef] 
82. Mensour, O.N.; El Ghazzani, B.; Hlimi, B.; Ihlal, A. A geographical information system-based multi-criteria method for the evaluation of solar farms locations: A case study in Souss-Massa area, southern Morocco. Energy 2019, 182, 900-919. [CrossRef]

83. Vafaeipour, M.; Zolfani, S.H.; Varzandeh, M.H.M.; Derakhti, A.; Eshkalag, M.K. Assessment of regions priority for implementation of solar projects in Iran: New application of a hybrid multi-criteria decision making approach. Energy Convers. Manag. 2014, 86, 653-663. [CrossRef]

84. Rios, R.; Duarte, S. Selection of ideal sites for the development of large-scale solar photovoltaic projects through Analytical Hierarchical Process-Geographic information systems (AHP-GIS) in Peru. Renew. Sustain. Energy Rev. 2021, 149, 111310. [CrossRef]

85. Aragonés-Beltrán, P.; Chaparro-González, F.; Pastor-Ferrando, J.; Rodríguez-Pozo, F. An ANP-based approach for the selection of photovoltaic solar power plant investment projects. Renew. Sustain. Energy Rev. 2010, 14, 249-264. [CrossRef]

86. Coe, R. Flood Risk Assessment On: Proposed Solar Farm, Mill Farm, Grantham, 2015. Rossi Long Consulting, UK. Available online: http:/ / planning.southkesteven.gov.uk/SKDC/S15-2137/806061.pdf (accessed on 7 December 2021).

87. ENTEC. Economic Analysis of Climate-Proofing Investment in Road and Rail Transport Sectors-UNDP Thailand/NDC Support Project: Delivering Sustainability through Climate Finance Actions in Thailand; ENTEC: Pathum Thani, Thailand, 2021.

88. Perera, A.; Nik, V.M.; Chen, D.; Scartezzini, J.-L.; Hong, T. Quantifying the impacts of climate change and extreme climate events on energy systems. Nat. Energy 2020, 5, 150-159. [CrossRef]

89. UNDRR. Asia-Pacific Regional Framework for NATECH (Natural Hazards Triggering Technological Disasters) Risk Management; UNDRR: Geneva, Switzerland, 2020.

90. Dowling, P. The impact of climate change on the European energy system. Energ Policy 2013, 60, 406-417. [CrossRef]

91. Shaqsi, A.Z.A.; Sopian, K.; Al-Hinai, A. Review of energy storage services, applications, limitations, and benefits. Energy Rep. 2020, 6, 288-306. [CrossRef]

92. Heo, J.; Moon, H.; Chang, S.; Han, S.; Lee, D.-E. Case Study of Solar Photovoltaic Power-Plant Site Selection for Infrastructure Planning Using a BIM-GIS-Based Approach. Appl. Sci. 2021, 11, 8785. [CrossRef]

93. Pašičko, R.; Branković, Č.; Šimić, Z. Assessment of climate change impacts on energy generation from renewable sources in Croatia. Renew. Energy 2012, 46, 224-231. [CrossRef]

94. Touili, N. Hazards, Infrastructure Networks and Unspecific Resilience. Sustainability 2021, 13, 4972. [CrossRef]

95. Schuss, C.; Leppänen, K.; Remes, K.; Saarela, J.; Fabritius, T.; Eichberger, B.; Rahkonen, T. Detecting defects in photovoltaic cells and panels and evaluating the impact on output performances. IEEE Trans. Instrum. Meas. 2016, 65, 1108-1119. [CrossRef]

96. Zhang, X.; Huang, G.; Zhou, X.; Liu, L.; Fan, Y. A multicriteria small modular reactor site selection model under long-term variations of climatic conditions-A case study for the province of Saskatchewan, Canada. J. Clean. Prod. 2021, $290,125651$. [CrossRef]

97. IRENA. Global Atlas for Renewable Energy: Overview of Solar and Wind Maps; IRENA: Abu Dhabi, United Arab Emirates, 2014.

98. Panteli, M.; Mancarella, P. Influence of extreme weather and climate change on the resilience of power systems: Impacts and possible mitigation strategies. Electr. Power Syst. Res. 2015, 127, 259-270. [CrossRef]

99. Eckstein, D.; Künzel, V.; Schäfer, L. Global Climate Risk Index 2021. Who Suffers Most from Extreme Weather Events? Germanwatch: Bonn, Germany, 2021.

100. Ward, P.; Kummu, M.; Lall, U. Flood frequencies and durations and their response to El Niño Southern Oscillation: Global analysis. J. Hydrol. 2016, 539, 358-378. [CrossRef]

101. Maruyama Rentschler, J.E.; Obolensky, M.A.B.; Kornejew, M.G.M. Candle in the Wind? Energy System Resilience to Natural Shocks, Energy System Resilience to Natural Shocks (17 June 2019); World Bank Policy Research Working Paper; World Bank: Washington, DC, USA, 2019.

102. ADB. Bangladesh: Spectra Solar Power Project; ADB: Manila, Philippines, 2019.

103. Sánchez-Lozano, J.M.; Teruel-Solano, J.; Soto-Elvira, P.L.; García-Cascales, M.S. Geographical Information Systems (GIS) and Multi-Criteria Decision Making (MCDM) methods for the evaluation of solar farms locations: Case study in south-eastern Spain. Renew. Sustain. Energy Rev. 2013, 24, 544-556. [CrossRef]

104. Effat, H.A. Selection of potential sites for solar energy farms in Ismailia Governorate, Egypt using SRTM and multicriteria analysis. Int. J. Adv. Remote Sens. GIS 2013, 2, 205-220.

105. Kengpol, A.; Rontlaong, P.; Tuominen, M. Design of a decision support system for site selection using fuzzy AHP: A case study of solar power plant in north eastern parts of Thailand. In Proceedings of the 2012 Proceedings of PICMET'12: Technology Management for Emerging Technologies, Vancouver, BC, Canada, 29 July-2 August 2012; pp. 734-743.

106. Jung, J.; Han, S.; Kim, B. Digital numerical map-oriented estimation of solar energy potential for site selection of photovoltaic solar panels on national highway slopes. Appl. Energy 2019, 242, 57-68. [CrossRef]

107. Agyekum, E.B.; Amjad, F.; Shah, L.; Velkin, V.I. Optimizing photovoltaic power plant site selection using analytical hierarchy process and density-based clustering-Policy implications for transmission network expansion, Ghana. Sustain. Energy Technol. Assess. 2021, 47, 101521. [CrossRef]

108. Margulis, S.; Hughes, G.; Schneider, R.; Pandey, K.; Narain, U.; Kemeny, T. Economics of Adaptation to Climate Change: Synthesis Report; World Bank: Washington, DC, USA, 2010.

109. ADB. Economic Analysis of Climate-Proofing Investment Projects; ADB: Manila, Philippines, 2015.

110. UNDP. Climate Change Benefit Analysis CCBA Guidelines; UNDP: New York, NY, USA, 2016. 
111. UNFCCC. Investment and Financial Flows to Address Climate Change. In Proceedings of the United Nations Framework Convention on Climate Change. 2007. Available online: http://unfccc.int/files/cooperation_and_support/financial_mechanism/ application/pdf/background_paper.pdf (accessed on 7 December 2021).

112. Gupta, A. Energy Security and Resilience in South Asia. Available online: https://www.nbr.org/publication/energy-securityand-resilience-in-south-asia/ (accessed on 7 December 2021).

113. NIBS. Natural Hazard Mitigation Saves: 2019 Report; NIBS: Washington, DC, USA, 2019.

114. OECD. Integrating Climate Change Adaptation Into Development Co-Operation: Policy Guidance; Organisation for Economic CoOperation and Development: Paris, France, 2009.

115. Australian Government. The Role of Regulation in Facilitating or Constraining Adaptation to Climate Change for Australian Infrastructure; Australian Government: Canberra, ACT, USA, 2011.

116. Mercure, J.-F.; Salas, P.; Vercoulen, P.; Semieniuk, G.; Lam, A.; Pollitt, H.; Holden, P.; Vakilifard, N.; Chewpreecha, U.; Edwards, N. Reframing incentives for climate policy action. Nat. Energy 2021, 6, 1133-1143. [CrossRef]

117. EU. Commission Notice-Technical Guidance on the Climate Proofing of Infrastructure in the Period 2021-2027; EU: Brussels, Belgium, 2021.

118. BOJ. Outline of Climate Response Financing Operations; BOJ: Tokyo, Japan, 2021.

119. Sagulpongmalee, K.; Therdyothin, A.; Nathakaranakule, A. Analysis of feed-in tariff models for photovoltaic systems in Thailand: An evidence-based approach. J. Renew. Sustain. Energy 2019, 11, 045903. [CrossRef]

120. IRENA. Renewable Energy Auctions: Analysing 2016; IRENA: Abu Dhabi, United Arab Emirates, 2017. 